Mariko Miyao • Takayuki Hosoi • Mitsuru Emi

Toshiaki Nakajima • Satoshi Inoue • Shinjiro Hoshino

Masataka Shiraki • Hajime Orimo • Yasuyoshi Ouchi

\title{
Association of bone mineral density with a dinucleotide repeat polymorphism at the calcitonin (CT) locus
}

Received: August 10, 2000 / Accepted: September 6, 2000

\begin{abstract}
Calcitonin (CT), a calcium-regulating hormone, lowers the calcium level in serum by inhibiting bone resorption. Because CT may play a role in the pathogenesis of osteoporosis, genetic variations in or adjacent to the $C T$ gene may be associated with variations in bone mineral density (BMD). The present study examined the correlation between a dinucleotide (cytosine-adenine; CA) repeat polymorphism at the $C T$ locus and BMD in 311 Japanese postmenopausal women (mean age, 64.1 years). Seven alleles were present in this population; each allele contained 10 , $11,16,17,18,19$, or $20 \mathrm{CA}$ repeats. Thus, we designated the respective genotypes A10, A11, A16, A17, A18, A19, and A20. The A10 and A17 alleles were the predominant alleles in the population studied. Z scores (a parameter representing deviation from the age-specific weight-adjusted average BMD) were compared between individuals that possessed one or two alleles of each genotype and those that did not possess the allele. Subjects who possessed one or two A10 alleles had lower BMD Z scores than those who did not (lumbar 2-4 BMD Z score; $-0.148 \pm 1.23$ vs $0.182 \pm 1.54$; $P=0.04)$. No significant relationships were observed between allelic status and background data or biochemical parameters. The significant association observed between $\mathrm{BMD}$ and genetic variations at the $C T$ locus implies that
\end{abstract}

M. Miyao $\cdot$ T. Hosoi $\cdot$ S. Inoue $\cdot$ S. Hoshino $\cdot$ H. Orimo $\cdot$ Y. Ouch Department of Geriatric Medicine, Graduate School of Medicine, The University of Tokyo, Tokyo, Japan

M. Emi $(\square) \cdot$ T. Nakajima

Department of Molecular Biology, Institute of Gerontology, Nippon Medical School, 1-396 Kosugi-cho, Nakahara-ku, Kawasaki 211-8533, Japan

Tel. +81-44-733-5230; Fax +81-44-733-5192

e-mail: memi@nms.ac.jp

M. Shiraki

Research Institute and Practice for Involutional Diseases, Nagano, Japan

T. Hosoi $\cdot$ H. Orimo

Department of Endocrinology, Tokyo Metropolitan Geriatric

Hospital, Tokyo, Japan polymorphism at this locus may be a useful marker for the genetic study of osteoporosis.

Key words Calcitonin gene . Bone mineral density • Osteoporosis · Microsatellite polymorphism · Risk factors

\section{Introduction}

Osteoporosis is characterized by low bone mass and by the microarchitectural deterioration of bone tissue, with a consequent increase in bone fragility and susceptibility to fracture (Consensus development conference 1993). Bone mineral density (BMD) is the primary factor affecting susceptibility to fracture and is determined by many genetic and lifestyle factors. Its predictive value is strongly supported by twin (Dequeker et al. 1987; Kelly et al. 1993; Pocock et al. 1987; Slemenda et al. 1991) and familial studies (Krall and Dawson-Hughes 1993; Lutz 1986; Seeman et al. 1989; Tylavsky et al. 1989). Knowing the genetic risk factors for an individual would assist in the diagnosis, prevention, and therapy of osteoporosis. Some genetic effects have been ascribed to polymorphisms of genes involved in bone metabolism, including the vitamin $\mathrm{D}$ receptor $(V D R)$ gene (Morrison et al. 1994), the estrogen receptor ( $E R)$ gene (Kobayashi et al. 1996; Sano et al. 1995), the type I collagen gene (Grant et al. 1996), the apolipoprotein E gene (Shiraki et al. 1997), the transforming growth factor $\beta$ gene (Langdahl et al. 1997), the parathyroid hormone (PTH) gene (Hosoi et al. 1998), and the interleukin 6 gene (Emi et al. 1999). However, whether these polymorphisms actually affect BMD is a matter of controversy.

Many endocrinological factors are known to play roles in bone maturation and in the process of bone loss that accompanies aging (Raisz 1988). Because it is entirely possible that the pathophysiology or key genetic background of each osteoporotic patient is heterogeneous, a rational approach to an understanding of the genetic background of osteoporosis would require an expansion of the panel of genes examined. 
Calcitonin (CT) is a polypeptide containing 32 amino acids that are synthesized by the parafollicular cells of the thyroid (Fischer and Born 1987). CT lowers serum calcium by inhibiting bone resorption and promoting the renal excretion of calcium. Increased bone resorption causes bone loss during aging in postmenopausal women. CT inhibits bone loss in estrogen-deficient individuals and is thought to suppress bone turnover (Gennari et al. 1992; MacIntyre et al. 1988; Owan and Ibaraki 1994).

A young osteoporotic man was reported to have an undetectable plasma CT concentration and a single base insertion in the intron separating exons IV and V of the $C T$ gene (Alevizaki et al. 1989). This evidence suggests that genetic variation in the $C T$ gene may contribute to the pathogenesis of osteoporosis. Recent studies (Masi et al. 1998; Taboulet et al. 1998) have shown a relationship between polymorphisms of the CT receptor gene and bone mineral density. However, no correlation between genetic variations in the $C T$ gene itself and bone metabolism has yet been shown, partly because no useful genetic markers for this gene have been recognized.

Recently, dinucleotide repeat polymorphic markers, or microsatellites, have been used to analyze multifactorial diseases (Houseman 1995). Microsatellite polymorphism can be employed for family-based studies, including sibpair analysis, and population-based association studies. In the present study, we used a newly isolated dinucleotide (cytosine-adenine; CA) repeat polymorphism at the $C T$ gene locus (Tsukamoto and Emi 1998) to analyze the relationship between allelic status and BMD in postmenopausal Japanese women.

\section{Subjects and methods}

\section{Subjects}

Genotype analysis was performed on samples collected from 311 healthy postmenopausal Japanese women (age, $64.1 \pm 8.2$ years; mean $\pm \mathrm{SD}$ ), who were recruited from among unrelated volunteers living in Nagano prefecture, Japan. DNA samples were obtained from the peripheral blood of subjects as previously described (Emi et al. 1999). Exclusion criteria for the present study included the presence of endocrinological disorders (such as hyperthyroidism, hyperparathyroidism, and diabetes mellitus); liver disease; or renal disease; the use of medicines known to affect bone metabolism (such as corticosteroids, anticonvulsants, heparin); or an unusual gynecological history. None of the women who participated in the present study were related, and all of the women were volunteers who gave their informed consent.

Measurement of bone mineral density (BMD) and biochemical markers

The spine BMD and total body BMD (BMD in $\mathrm{g} / \mathrm{cm}^{2}$ ) of each participant were measured using dual-energy X-ray absorptiometry (DPX-L; Lunar, Madison, WI, USA). The following biochemical parameters were measured, as described elsewhere (Shiraki 1997): serum concentration of calcium (Ca), phosphate (P), alkaline phosphatase (ALP), intact osteocalcin (I-OC; enzyme-linked immunosorbent assay [ELISA], Teijin, Tokyo, Japan), N-fragment osteocalcin (N-OC; ELISA, Teijin), intact parathyroid hormone (intact PTH; IRMA kit, Nichols Institute Diagnostics, San Juan Capistrano, CA, USA), and calcitonin (CT; ELISA, Mitsubishi Chemical, Tokyo, Japan). The minimum detectable level of CT was $12.5 \mathrm{pg} / \mathrm{ml}$. In addition, the calcium/creatine ratio, the phosphate/creatinine ratio, the amount of pyridinoline (Pyr; by the HPLC method), and the amount of deoxypyridinoline (Dpyr; by the HPLC method) present in the urine of each woman were measured. $\mathrm{Z}$ scores (a parameter representing deviation from the age-specific weight-adjusted average BMD) were used to analyze the BMD data. Data from 20,000 Japanese women were used to calculate $\mathrm{Z}$ scores, using Lunar DPXL installed software.

\section{Determination of microsatellite polymorphism}

Isolation and characterization of a microsatellite polymorphism at the $C T$ locus was reported by us (Tsukamoto and Emi 1998). This polymorphism was genotyped by polymerase chain reaction (PCR), using Cy5-labeled forward primer (CT-4F:5'-GGAGACAAACAGGGATGACA-3', Pharmacia Amersham, Tokyo, Japan) and unlabeled reverse primer (CT-4R:5' -CAGAAACATGGTGTGCCA GC-3'). The PCR reaction was carried out in a final volume of $25 \mu \mathrm{l}$ containing $100 \mathrm{ng}$ of genomic DNA obtained from peripheral white blood cells, $10 \mathrm{pmol}$ of each primer, $200 \mathrm{mM}$ dNTP, $10 \mathrm{mM}$ Tris- $\mathrm{HCl}(\mathrm{pH} 8.3), 50 \mathrm{mM} \mathrm{KCl}$, $1.5 \mathrm{mM} \mathrm{MgCl} 2,0.001 \%$ gelatin, and $0.1 \mathrm{U}$ Taq DNA polymerase (Ampli Taq Gold; PE Biosystems, Tokyo, Japan) (Tsukamoto et al. 1998; Watanabe et al. 1998). Thirty PCR cycles (each $30 \mathrm{~s}$ at $94^{\circ} \mathrm{C}, 60 \mathrm{~s}$ at $58^{\circ} \mathrm{C}$, and $60 \mathrm{~s}$ at $72^{\circ} \mathrm{C}$ ) were performed (Hirayama et al. 1998). The resulting PCR products were then electrophoresed in a $2 \%$ agarose gel. An aliquot from each reaction was mixed with formamide/blue dextran gel-loading buffer, internal size marker (100bp, $200 \mathrm{bp}$; Pharmacia Amersham), heated at $95^{\circ} \mathrm{C}$ for $5 \mathrm{~min}$, and cooled on ice for $5 \mathrm{~min}$. Subsequently, the products were separated on a $6 \%$ urea gel ( $6 \%$ Long Ranger; Takara Shuzou, $6 \mathrm{M}$ Urea, $0.5 \times$ Tris Bolate EDTA [TBE]) at $55 \mathrm{~W}$ for $700 \mathrm{~min}$, using an ALFexpress DNA sequencer (Pharmacia Amersham).

A genomic DNA homozygous for the most frequent size was subcloned in PCRII plasmid (Invitrogen, Carlsbad, CA, USA) and sequenced using an autosequencer equipped with an Autoread sequencing kit (Pharmacia Amersham); this contained 17(CA) repeats and the allele was named A17. The sizes of other PCR products were determined through comparison with the sequenced sample named A17, using Fragment Manager software (Pharmacia Amersham). We determined the names of the other samples comparing the size with A17. 
Statistical analysis

Non-parametric Student-Neumann-Klaus $t$-test has been routinely used as a standard method for statistical analysis in correlating allelic status with quantitative traits, such as BMD, blood pressure (Sano et al. 1995; Kobayashi et al. 1996; Shiraki et al. 1997; Hosoi et al. 1998; Tsukamoto et al. 1999; Ogawa et al. 2000). In the present study, we followed this convention of analyzing quantitative traits by StudentNewman-Klaus $t$-test. Therefore, comparisons of $Z$ scores and biochemical markers between the group of individuals possessing one or two alleles of each genotype and the group that did not possess that genotype were performed using Student's $t$-test (StatView-J 4.5, Abacus Concepts, Tokyo, Japan). A $P$ value less than 0.05 was considered significant. Other methods, including the $\chi^{2}$ test, Wilcoxon signed-ranks test, and analysis of variance, may also be used occasionally; for example, the $\chi^{2}$ test is used to analyze deviations of genotype frequencies from Hardy-Weinberg expectation in case-control comparisons.

\section{Results}

Using molecular size markers and the installed software, we determined the number of CA repeats for each allele by DNA sequencing. PCR products were shown to contain 10, $11,16,17,18,19$, or $20 \mathrm{CA}$ repeats. We designated these alleles as A10, A11, A16, A17, A18, A19, and A20, respectively, and determined the genotype of each of the 311 postmenopausal Japanese women. The allele distribution among the 622 chromosomes is shown in Fig. 1. CA repeats 10 and 17 were the dominant types.
The subjects were then grouped according to genotype, and their BMD and BMD Z scores were statistically compared between the group with a given genotype and all subjects without that genotype. The $\mathrm{Z}$ score for lumbar BMD was significantly different between subjects with the A10 genotype and those without A10 (Fig. 2). Other genotypes did not appear to affect the BMD Z scores. We then compared demographic and baseline data between the groups classified as A10 and non-A10 and found no significant differences (Table 1). Similarly, comparisons of biochemical parameters, including bone metabolic parameters and serum CT concentration, revealed no significant differences (Table 2). Of the 147 women possessing the A10 allele, 25 were homozygous at this locus. However, no significant differences in the BMD Z score were detected between women who were homozygous for the A10 allele and those who were heterozygous (data not shown).

Table 1. Comparison of background data in Japanese menopausal women with and without an A10 allele at the $C T$ locus

\begin{tabular}{lccc}
\hline & $\begin{array}{l}\text { A10 }(+) \\
(n=147)\end{array}$ & $\begin{array}{l}\text { A10 }(-) \\
(n=161)\end{array}$ & $P$ value \\
\hline Age (years) & $65.2 \pm 9.4$ & $64.1 \pm 8.1$ & 0.42 \\
Years after menopause & $15.5 \pm 9.1$ & $14.5 \pm 8.3$ & 0.25 \\
Age at menarche (years) & $16.0 \pm 1.7$ & $15.4 \pm 1.8$ & 0.16 \\
BH (cm) & $151.2 \pm 5.6$ & $150.7 \pm 6.1$ & 0.59 \\
BW (kg) & $52.2 \pm 8.4$ & $51.2 \pm 7.9$ & 0.92 \\
Cr (mg/dl) & $0.65 \pm 0.29$ & $0.76 \pm 0.24$ & 0.54 \\
\hline
\end{tabular}

All data values are expressed as means \pm SD. There were no differences between the groups

$\mathrm{BH}$, Body height; BW, body weight; Cr, creatinine; CT, calcitonin
Fig. 1. Frequency distribution of calcitonin $(C T)$ dinucleotide repeat polymorphism in Japanese postmenopausal women $C A$, Cytosine-adenine

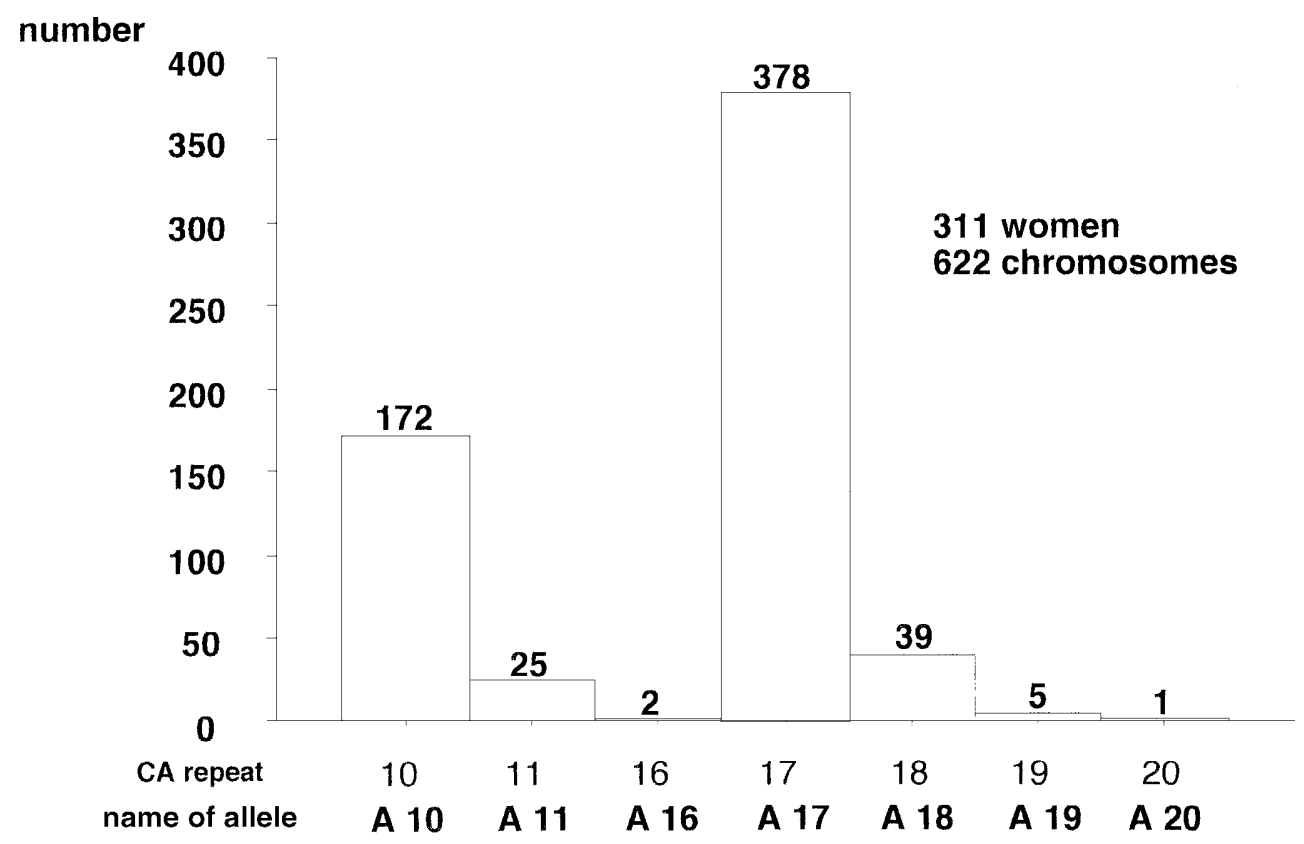




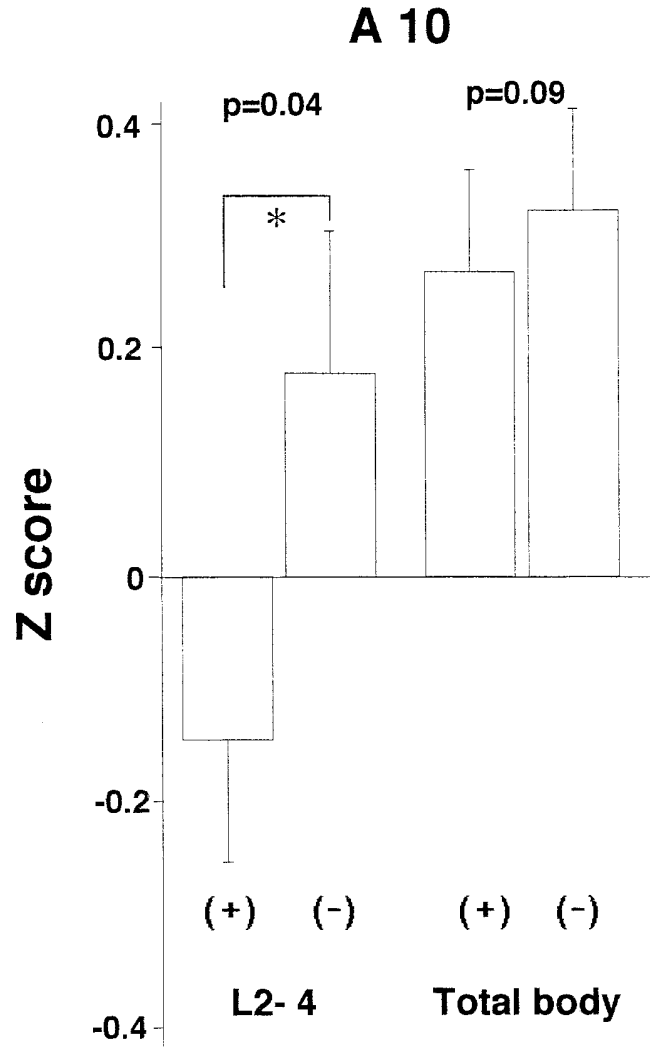

Fig. 2. Comparison of bone mineral density (BMD) between subjects with and without the $C T$ A10 allele. Z score values for lumbar spine BMD (L2-4) and total body BMD (total body) were compared between the subjects with $(+)$ and without $(-)$ a $C T$ allele. $P$ values are shown when they are less than 0.10 . The difference between A10 $(+)$ and A10 ( -$)$ was significant. $(* P=0.04)$. See text for explanation of 2 score

\section{Discussion}

The present study used a newly isolated dinucleotide repeat polymorphism adjacent to the $C T$ gene to associate an allelic genotype, A10, with lower BMD in Japanese postmenopausal women. The data presented in this report suggest that variation or mutation in or adjacent to the $C T$ gene may affect bone metabolism and eventually cause variations in BMD. However, because our study population consisted of a single ethnic group and was rather small in scale, it would be of value to have further confirmation in different populations to allow definitive conclusions to be drawn regarding the association between $\mathrm{CT}$ and $\mathrm{BMD}$.

The $C T$ gene is located at 11p15.1-15.2 (Hoovers et al. 1993). Calcitonin gene-related peptide (CGRP) is an alternative splicing product of the $C T$ gene transcript (Rosenfeld et al. 1983). Recently, neuronal factors, in particular, neuropeptides, have been reported to regulate bone cells (Konttinen et al. 1996). CGRP has been reported to recruit macrophages into osteoclast-like cells (Owan and Ibaraki 1994), to inhibit bone resorption (Roos et al. 1986), and to stimulate osteogenesis (Bernard and Shih 1990). It is possible that the allelic genotype associated with the lower BMD in our test subjects may be in linkage disequilibrium
Table 2. Effects of carriage of the A10 allele on bone metabolic markers and calcium-regulating hormones

\begin{tabular}{lccc}
\hline & $\begin{array}{l}\text { A10 }(+) \\
(n=147)\end{array}$ & $\begin{array}{l}\text { A10 }(-) \\
(n=164)\end{array}$ & $P$ value \\
\hline Intact-OC $(\mathrm{ng} / \mathrm{ml})$ & $7.1 \pm 3.4$ & $7.8 \pm 3.7$ & 0.12 \\
U-pyr $(\mathrm{pmol} / \mu \mathrm{mol})$ & $33.4 \pm 10.4$ & $33.5 \pm 9.9$ & 0.90 \\
U-deoxypyr. $(\mathrm{pmol} / \mu \mathrm{mol})$ & $7.2 \pm 2.3$ & $7.2 \pm 2.3$ & 0.87 \\
Intact PTH $(\mathrm{pg} / \mathrm{ml})$ & $37.0 \pm 13.9$ & $36.7 \pm 13.2$ & 0.35 \\
Calcitonin $(\mathrm{pg} / \mathrm{ml})$ & $23.0 \pm 10.8$ & $24.1 \pm 9.6$ & 0.37 \\
$1,25(\mathrm{OH})_{2} \mathrm{D}_{3}(\mathrm{ng} / \mathrm{ml})$ & $32.4 \pm 13.2$ & $33.8 \pm 11.6$ & 0.35 \\
\hline
\end{tabular}

All data values are expressed as means $\pm \mathrm{SD}$. The $C T$ genotype, A10, did not affect bone metabolic markers or calcium-regulating hormone Intact-OC, intact-osteocalcin; U-pyr, urinary pyridinoline; Udeoxypry., urinary deoxypyridinoline; intact $\mathrm{PTH}$, intact parathyroid hormone; $1,25(\mathrm{OH})_{2} \mathrm{D}_{3}, 1,25$-dehydroxyvitamin D3

with a mutation in CGRP; another possibility is involvement of the gene encoding PTH, which lies in the same genomic vicinity as $C T$ (Kittur et al. 1985). This spatial relationship is intriguing when we consider the importance of both hormones in calcium metabolism.

No significant differences were observed in bone metabolic markers, including serum CT, between the group with A10 and the group without this genotype. In this study, the minimum detectable level of CT $(12.5 \mathrm{pg} / \mathrm{ml})$ was relatively high; a total of 58 subjects (18.6\%) had CT under this level, and the frequency distribution of subjects with an undetectable level in each group was not different (data not shown). A more sensitive assay of CT would help to elucidate this issue.

It is well established that CT is useful in the treatment of osteoporosis (Gennari et al. 1992; MacIntyre et al. 1988; Owan and Ibaraki 1994). Moreover, a report of $C T$ gene mutation in a young patient with osteoporosis also supports the idea that $\mathrm{CT}$ is important in maintaining bone mass (Alevizaki et al. 1989). Although the correlation between CT plasma level and BMD remains unclear (Chesnut et al. 1980; Leggate et al. 1984; Prince et al. 1989), we can speculate that a variation in the $C T$ locus may be correlated to variations in the effect of $\mathrm{CT}$ in maintaining calcium homeostasis. For example, the CT secretory reaction to calcium infusion in osteoporotic women was reported to be lower than that in normal women (Taggart et al. 1982). In addition, it was reported that $\mathrm{CT}$ secretion response decreased with aging (Deftos et al. 1980). Clarification of the relationship between the $C T$ gene and osteoporosis requires further knowledge of the regulatory mechanisms of gene expression and post-translational processing of $C T$ gene. To that end, a future search for single nucleotide polymorphisms (SNPs) that may affect calcium metabolism, as well as functional studies of the involvement of these SNPs in the pathogenesis of osteoporosis, would be warranted.

Acknowledgments The authors wish to thank Ms. M. Kobayashi for her technical assistance. This work was supported in part by grants from the Foundation for Comprehensive Research on Longevity and Health, and from the Ministry of Education and Science of Japan; a special grant for Strategic Advanced Research on "Genome Science" from the Ministry of Education, Science, Sports, and Culture of Japan; 
by a Research Grant for Research from the Ministry of Health and Welfare of Japan; and by a Research for the Future Program Grant of The Japan Society for the Promotion of Science.

\section{References}

Alevizaki M, Stevenson JC, Girgis SI, MacIntyre I, Legon S (1989) Altered calcitonin gene in a young patient with osteoporosis. BMJ 298:1215-1216

Bernard GW, Shih C (1990) The osteogenic-stimulating effect of neuroactive calcitonin gene-related peptide. Peptides 11:625-632

Chesnut CH 3d, Baylink DJ, Sisom K, Nelp WB, Roos BA (1980) Basal plasma immunoreactive calcitonin in postmenopausal osteoporosis. Metabolism 29:559-562

Consensus development conference (1993) Diagnosis, prophylaxis and treatment of osteoporosis. Am J Med 94:646-650

Deftos LJ, Weisman MH, Williams GW, Karpf DB, Frumar AM, Davidson BJ, Parthemore JG, Judd HL (1980) Influence of age and sex on plasma calcitonin in human beings. N Engl J Med 302:13511353

Dequeker J, Nijs J, Verstraeten A, Geusens P, Gevers G (1987) Genetic determinants of bone mineral content at the spine and radius: a twin study. Bone 8:207-209

Emi M, Keicho N, Tokunaga K, Katsumata H, Souma S, Nakata K, Taguchi K, Ohishi N, Azuma A, Kudoh S (1999) Association of diffuse panbronchiolitis with microsatellite polymorphism at the human interleukin 8 (IL-8) locus. J Hum Genet 44:169-172

Fischer JA, Born W (1987) Calcitonin gene products:evolution, expression and biological targets. Bone Miner 2:347-359

Gennari C, Agnusdei D, Montagnani M, Gonnelli S, Civitelli R (1992) An effective regimen of intranasal salmon calcitonin in early postmenopausal bone loss. Calcif Tissue Int 50:381-383

Grant SF, Reid DM, Blake G, Herd R, Fogelman I, Ralston SH (1996) Reduced bone density and osteoporosis associated with a polymorphic Sp1 binding site in the collagen type I a 1 gene. Nature Genet 14:203-205

Hirayama T, Yamaki E, Hara A, Tsuji M, Hashimoto K, Yamamoto M, Emi M (1998) Five familial hypercholesterolemic kindreds in Japan with novel mutation of the LDL receptor gene. J Hum Genet 43:250-254

Hoovers JM, Redeker E, Speleman F, Hoopner JW, Bhola S, Bliek J, van Roy N, Leschot NJ, Westerveld A, Mannens M (1993) Highresolution chromosomal localization of the human calcitonin/ CGRP/IAPP gene family members. Genomics 15:525-529

Hosoi T, Miyao M, Inoue S, Hoshino S, Shiraki M, Orimo H, Ouchi Y (1998) Association study of parathyorid hormone gene polymorphism and bone mineral density in Japanese postmenopasusal women. Calcif Tissue Int 64:205-208

Housman D (1995) Human DNA polymorphism. N Engl J Med 332:318-320

Kelly PJ, Nguyen T, Hopper J, Pocock N, Sambrook P, Eisman J (1993) Changes in axial bone density with age: a twin study. J Bone Miner Res 8:11-17

Kittur SD, Hoppener JW, Antonarakis SE, Daniels JD, Meyers DA Maestri NE, Jansen M, Korneluk RG, Nelkin BD, Kazazian HH Jr (1985) Linkage map of the short arm of human chromosome 11: location of the genes for catalase, calcitonin, and insulin-like growth factor II. Proc Natl Acad Sci USA 82:5064-5067

Kobayashi S, Inoue S, Hosoi T, Ouchi Y, Shiraki M, Orimo H (1996) Association of bone mineral density with polymorphism of the estrogen receptor gene. J Bone Miner Res 11:306-311

Konttinen YT, Imai S, Suda A (1996) Neuropeptides and the puzzle of bone remodeling. Acta Orthop Scand 67:632-639

Krall EA, Dawson-Hughes B (1993) Heritable and life-style determinants of bone mineral density. J Bone Miner Res 8:1-9

Langdahl BL, Knudsen JY, Jensen HK, Gregersen N, Eriksen EF (1997) A sequence variation:713-8delC in the transforming growth factor-beta I gene has higher prevalence in osteoporotic women than in normal women and is associated with very low bone mass in osteoporotic women and increased bone turnover in both osteoporotic and normal women. Bone 20:289-294
Leggate J, Farish E, Fletcher CD, McIntosh W, Hart DM, Sommerville JM (1984) Calcitonin and post menopausal osteoporosis. Clin Endocrinol (Oxf) 20:85-92

Lutz J (1986) Bone mineral, serum calcium and dietary intakes of mother/daughter pairs. Am J Clin Nutr 44:99-106

MacIntyre I, Stevenson JC, Whitehead MI, Wimalawansa SJ, Banks LM, Healy MJ (1988) Calcitonin for prevention of postmenopausal bone loss. Lancet 23:900-902

Masi L, Becherini L, Colli E, Gennari L, Mansani R, Falchetti A, Becorpi AM, Cepollaro C, Gonnelli S, Tanini A, Brandi ML (1998) Polymorphisms of the calcitonin receptor gene are associated with bone mineral density in postmenopausal Italian women. Biochem Biophys Res Commun 248:190-195

Morrison NA, Qi JC, Tokita A, Kelly PJ, Crofts L, Nguyen TV, Sambrook PN, Eisman JA (1994) Prediction of bone density from vitamin D receptor alleles. Nature 367:284-287

Ogawa S, Emi M, Shiraki M, Hosoi T, Ouchi Y, Inoue S (2000) Association of estrogen receptor beta (ESR2) gene polymorphism with blood pressure. J Hum Genet 45:327-330

Owan I, Ibaraki K (1994) The role of calcitonin gene-related peptide (CGRP) in macrophages:the presence of functional receptors and effects on proliferation and differentiation into osteoclast-like cells. Bone Miner 24:151-164

Pocock NA, Eisman JA, Hopper JL, Yeates MG, Sambrook PN, Eberl S (1987) Genetic determinants of bone mass in adults. A twin study. J Clin Invest 80:706-710

Prince RL, Dick IM, Price RI (1989) Plasma calcitonin levels are not lower than normal in osteoporotic women. J Clin Endocrinol Metab 68:684-687

Raisz LG (1988) Local and systemic factors in the pathogenesis of osteoporosis. N Engl J Med 318:818-828

Roos BA, Fischer JA, Pignat W, Alander CB, Raisz LG (1986) Evaluation of the in vivo and in vitro calcium-regulating actions of noncalcitonin peptides produced via calcitonin gene expression. Endocrinology 118:46-51

Rosenfeld MG, Mermod JJ, Amara SG, Swanson LW, Sawchenko PE, Rivier J, Vale WW, Evans RM (1983) Production of a novel neuropeptide encoded by the calcitonin gene via tissue-specific RNA processing. Nature 304:129-135

Sano M, Inoue S, Hosoi T, Ouchi Y, Emi M, Shiraki M, Orimo H (1995) Association of estrogen receptor dinucleotide repeat polymorphism with osteoporosis. Biochem Biophys Res Commun 217:378-383

Seeman E, Hopper JL, Bach LA, Cooper ME, Parkinson E, McKay J, Jerums G (1989) Reduced bone mass in daughters of women with osteoporosis. N Engl J Med 320:554-558

Shiraki M, Shiraki Y, Aoki C, Hosoi T, Inoue S, Kaneki M, Ouchi Y (1997) Association of bone mineral density with apolipoprotein $\mathrm{E}$ phenotype. J Bone Miner Res 12:1438-1445

Slemenda CW, Christian JC, Williams CJ, Norton JA, Johnston CC Jr (1991) Genetic determinants of bone mass in adult women: a reevaluation of the twin model and the potential importance of gene interaction of heritability estimates. J Bone Miner Res 6:561-567

Taboulet J, Frenkian M, Frendo JL, Feingold N, Jullienne A, deVernejoul MC (1998) Calcitonin receptor polymorphism is associateid with a decreased fracture risk in post-menopausal women. Hum Mol Genet 7:2129-2133

Taggart HM, Chesnut CH 3d, Ivey JL, Baylink DJ, Sisom K, Huber MB, Roos BA (1982) Deficient calcitonin response to calcium stimulation in postmenopausal osteopososis? Lancet I:475-478

Tsukamoto K, Emi M (1998) A polymorphic CA repeat sequence at the human calcitonin locus. J Hum Genet 43:146-147

Tsukamoto K, Haruta K, Shiba T, Emi M (1998) Isolation and mapping of a polymorphic CA repeat sequence at the human interleukin 6 locus. J Hum Genet 43:71-72

Tsukamoto K, Yoshida H, Watanabe S, Suzuki T, Miyao M, Hosoi T, Orimo H, Emi M (1999) Association of radial bone mineral density with CA repeat polymorphism at the interleukin 6 locus in postmenopausal Japanese women. J Hum Genet 44:148-151

Tylavsky FA, Bortz AD, Hancock RL, Anderson JJ (1989) Familial resemblance of radial bone mass between premenopausal mothers and their college-age daughters. Calcif Tissue Int 45:265-272

Watanabe I, Tsukamoto K, Shiba T, Emi M (1998) Isolation and radiation hybrid mapping of dinucleotide repeat polymorphism at the human matrix Gla protein (MGP) locus. J Hum Genet 43:75-76 